\title{
POSTAĆ HYPATIOSA, PIERWSZEGO IGUMENA KLASZTORU W RUFINIANACH, A IDEAŁ ŚWIĘTEGO MĘżA W PÓŹNOANTYCZNYM SPOŁECZEŃSTWIE WSCHODNIEGO CESARSTWA W ŚWIETLE RELACJI KALLINIKOSA
}

Chrześcijański święty mąż jest postacią, która wielokrotnie budziła zainteresowanie historyków. Pojawienie się tego fenomenu, jego trwałość i znaczenie często usiłowano wyjaśnić. Podstawowy w tych badaniach jest artykuł P. Browna ${ }^{1}$, który stanowi zwrot $\mathrm{w}$ dotychczasowym traktowaniu postaci świętego męża w późnym antyku. Niestety, wnioski zawarte w tym artykule ograniczają się do spojrzenia na interesujący nas problem jedynie oczyma historyka społecznego, w większości są więc natury socjologicznej. Widoczny jest tu więc brak badań natury religijnej czy kulturowej, które również muszą być przeprowadzone, jeżeli chcemy otrzymać obraz pełny, a nie tylko jego wycinek.

\section{POWSTANIE IDEAŁU ŚWIĘTEGO MĘŻA}

Socjologiczne podejście do świętego męża nie uwzględnia bardzo ważnej roli kulturowych i religijnych uwarunkowań, które powodowały, iż święty mąż opuszczał swoje dotychczasowe środowisko i udawał się na pustynię. Ograniczanie analizy fenomenu świętego męża wyłącznie do zjawisk społecznych czyni motywy, jakimi się kierował w podejmowaniu tak ważnej decyzji, niezrozumiałymi. Wizja socjologiczna może thumaczyć funkcjonowanie świętego w społeczności, nie jest w stanie jednak wytłumaczyć przyczyn jego pojawienia się w świecie późnego antyku. Poszukując kulturowych korzeni, z których mógł

${ }^{1}$ Por. P. Brown, The Rise and Function of the Holy Man in Late Antiquity, "Journal of Roman Studies" 41(1971) 80-101. Zagadnieniu szczególnej roli świętego męża jako syryjskiego patrona wobec specyficznych dla tej krainy stosunków miasta i wsi P. Brown poświęcił też artykuł: Town, Village and Holy Man: The Case of Syria, w: Society and the Holy in Late Antiquity, Berkeley 1982, 153-165; zob. też interesujące artykuły: E. Wipszycka, Wierni u stóp Symeona Stupnika. O spotecznej funkcji ascetyzmu syryjskiego, RTK 26(1979) z. 4, 91-117; zob. także R. Browning, The 'Low Level' Saint's Life in the Early Byzantine World, w: The Byzantine Saint, ed. S. Hackel, London 1981 , s. $117-127$. 
wyrosnąć ideał świętego męża, musimy za R. Browningiem odrzucić koncepcję przejęcia owego ideału od pogańskich szamanów ${ }^{2}$. Podobnie jesteśmy skłonni odrzucić pogląd, iż święty mąż był efektem przejęcia przez chrześcijaństwo

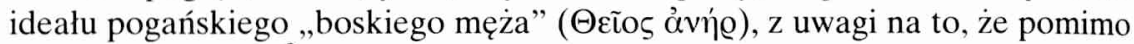
wielu podobieństw ${ }^{3}$ oba te ideały różnią się między sobą zdecydowanie swą funkcją społeczną i stosunkiem do prostej ludności ${ }^{4}$. Podobnie rzecz się ma z manichejskimi electi, u których również próbowano doszukać się wzorca świętego męża 5 .

Jeżeli więc nie mamy do czynienia $\mathrm{z}$ pewnym przejęciem ideału hellenistycznego czy manichejskiego, to musimy szukać przyczyn pojawienia się świętego męża wewnątrz kulturowych i religijnych ideałów, które znajdują się w samym chrześcijaństwie. Ideały takie znajdujemy przede wszystkim na kartach Pisma św., podobnie zresztą jak to czynili chrześcijanie późnego antyku. Pismo św. bowiem, zwłaszcza zaś Ewangelie i Psalmy, stanowiły podstawę edukacji monastycznej, a częstokroć także wychowania w świeckich rodzinach

${ }^{2}$ Por. R. Browning, The 'Low Level' Saint's Life, s. 123-124.

${ }^{3}$ Cechy „,boskiego męża” zostały zebrane w: M. Dzielska, „Boscy mężowie”, „Znak” 50(1998) nr 515, 41-54. Posiadał on wiele cech podobnych do świętego męża, takich jak panowanie nad demonami i siłami natury, przenikanie ludzkich myśli, przewidywanie przyszłości, uprawianie ascezy, itd. Oba ideały powstały poza tym w podobnym okresie czasowym we wschodniej części Imperium Rzymskiego.

4 „Boski mąż” zwracał się zazwyczaj do wybranego grona słuchaczy, nie był otwarty na rzesze ludności, zwłaszcza tej uboższej, starał się nie wchodzić w relacje ze zwykłymi ludźmi, a przez to często zamykał się w samotności czy też w wąskim gronie najbliższych; uważal się też za przedstawiciela „świętej rasy”, por. M. Dzielska, „Boscy mężowie”, s. 48 i 51. Chrześcijański święty mąż natomiast nie pogardzał zwykłymi ludźmi, zawsze był gotowy do pomocy, zwłaszcza tym najuboższym. Funkcjonował przecież jako patron, działał także wśród biedoty miejskiej, por. Evagrius Scholasticus, Historia ecclesiastica IV 34 (fragment o Symeonie Salosie), a także H.J.W. Drijvers, Hellenistic and Oriental Origins, w: The Byzantine Saint, s. 26-27; R. Browning, The Low Level' Saint's Life, s. 121-123. Jest to różnica zasadnicza, która wynika z podstawowej cechy ideału chrześcijańskiej świętości - miłości bliźniego.

${ }^{5}$ Por. np. A. Vööbus, History of Ascetism in Syrian Orient. Early monasticism in Mesopotamia and Syria, Louvain 1960, s. 158. Również i u manichejskich electi można dostrzec silny nacisk na ascezę. Podobnie jednak, jak w przypadku „boskich męźów” społeczny charakter ideału świętego męża każe odrzucić takie powiązanie. Electi stanowili elitę manicheizmu, która nie angażowała się w problemy społeczeństwa. I chociaż manicheizm mógł mieć pewien wpływ na ruch ascetyczno-monastyczny w chrześcijaństwie, to nie można w pełni łączyć chrześcijańskiej ascezy $\mathrm{z}$ religią anty-kosmicznego i anty-cielesnego dualizmu, por. H.J.W. Drijvers, Hellenistic and Oriental Origins, s. 30-31. Niektórzy współcześni badacze łączyli z wpływami manichejskimi syryjski tzw. proto-monastycyzm, a zwłaszcza jego nacisk na celibat. Musimy jednak dość krytycznie podejść do tej hipotezy, z uwagi na wielokrotne odżegnywanie się Efrema (głównego twórcy tego ascetycznego ruchu syryjskiego) od poglądów marcjonitów i manichejczyków na nieczystość małżeństwa. Źródło nacisku Efrema i innych ascetów syryjskich na bezżenność leżało zdecydowanie gdzie indziej, por. S. Brock, The Ascetic Ideal: Saint Ephrem and Proto-monasticism, w: The Luminous Eye. The Spiritual World Vision of Saint Ephrem, Kalamazoo 1985, s. 139. 
chrześcijańskich $^{6}$. Na kartach Ewangelii znajdowano przede wszystkim Chrystusa, który stał się niedoścignionym Mistrzem dla chrześcijanina. Nic więc dziwnego, że starano się ukazywać świętego męża jako tego, który naśladuje ten Wzór, a przez to staje się imago Christi, obrazem Chrystusa. Wiele elementów znanych nam Żywotów zdaje się potwierdzać, że to właśnie założenie przyświeca ich autorom ${ }^{7}$. H.J.W. Drijvers dokonał analizy Żywota pewnego świętego męża z Edessy właśnie pod kątem przedstawienia go jako drugiego Chrystusa $^{8}$. Podobnego zabiegu można dokonać z wieloma innymi Żywotami. Okazuje się, że opisanie świętego ma cel przede wszystkim religijny ${ }^{9}$. Podobnie jak motywacja do porzucenia świata i udania się na pustynię ma zwykle związek z jakimś fragmentem Pisma św., który święty usłyszał lub przeczytał ${ }^{10}$, tak również całe jego życie jest skonstruowane jako żywa ilustracja Biblii. Święty mąż staje się żywym, pulsującym obrazem Chrystusa, Jana Chrzciciela, Abrahama czy Mojżesza. W żywocie Symeona zawartym w Historia religiosa Teodoreta z Cyru czytamy, że młody Symeon w dzieciństwie uczył się paść trzody, aby przez to móc upodobnić się do wielkich postaci Starego Testamentu: Jakuba, Józefa, Mojżesza, Dawida czy Micheasza ${ }^{11}$. Podobnie jak Chrystus, Symeon przeżył czterdziestodniowy post bez jedzenia ${ }^{12}$. Naśladując Zbawiciela kazał paralitykowi nieść swoje łoże ${ }^{13}$. Antoni, ojciec monastycyzmu egipskiego, uprawiał znów ascezę naśladując Eliasza ${ }^{14}$. Generalnie święci mężowie dość rzadko wychodzą poza biblijny kanon cudów ${ }^{15}$. Słynni święci poddają swe ciało umartwieniom także po to, aby upodobnić się do cierpiącego Jezusa, a nocne modlitwy stylitów są jakby powtórzeniem modlitwy Chrystusa w Getsemani ${ }^{16}$. Powyższe uwagi każą nam zrewidować poglądy sprowadzające przy-

${ }^{6} \mathrm{~W}$ tej kwestii zob. N.W. Pigulewska, Kultura syryjska we wczesnym średniowieczu, tłum. Cz. Mazur, Warszawa 1989, s. 42-53.

${ }^{7}$ Na przykład święty mąż często w młodości nie zachowywał się jak przeciętne dziecko, ale podobnie jak Chrystus , czynit postępy w mądrości, w latach $i$ w tasce u Boga i u ludzi” (Łk 2, 52).

${ }^{8}$ Por. Drijvers, Hellenistic and Oriental Origins, s. 27-28.

${ }^{9}$ Por. Browning, The 'Low Level' Saint's Life, s. 117.

${ }^{10}$ Tak było w słynnym przypadku Antoniego Egipskiego (Athanasius, Vita Antonii 2), czy Symeona Stylity (Theod., Historia religiosa 26,2 ).

${ }^{11}$ Por. Historia religiosa 26, 2, PG 82, 1465 lub SCh 257 (L'histoire des moines de Syrie, Paris 1977), s. 160, thum. K. Augustyniak: Teodoret biskup Cyru, Dzieje miłości Bożej, ŹM 7, TyniecKraków 1994, s. 263.

${ }_{12}$ Por. tamże, 26, 9.

13 Por. tamże, 26, 17.

${ }^{14}$ Por. Athanasius, Vita Antonii 7, PG 26, 852 lub SCh 400 (Vie d'Antoine, éd. G.J.M. Bartelink, Paris 1994), s. 150, thum. Z. Brzostowska: Św. Atanazy Aleksandryjski, Żywot świętego Antoniego - Św. Antoni, Pisma, Warszawa 1987), s. 61.

${ }^{15}$ Por. R. Wiśniewski, Cuda i świętość, w: Chrześcijaństwo u schyłku starożytności. Studia źródtoznawcze, praca zbiorowa pod red. T. Derdy i E. Wipszyckiej, Warszawa 1997, s. 288 oraz 291. Dzieje się tak z uwagi na to, że biblijny pierwowzór był rękojmią jego prawdziwości.

${ }^{16}$ Por. Historia religiosa $26,6$. 
czyny pojawienia się świętego męża, jego roli i pozycji w świecie późnoantycznym jedynie do aspektów socjologicznych.

\section{HYPATIOS W ŚWIETLE RELACJI KALLINIKOSA A IDEAE ŚWIĘTEGO MĘŻA}

Żywot Hypatiosa (Vita Hypatii $=\mathrm{VH}$ ) należy do gatunku hagiograficznego, a ściślej do hagiografii mniszej, która od czasu Żywota Antoniego Atanazego z Aleksandrii rozwijała się szeroko w literaturze chrześcijańskiej ${ }^{17}$. Przyjmuje się, że Żywot ten został napisany w latach $447-450^{18}$ przez ucznia Hypatiosa, mnicha Kallinikosa z klasztoru Rufinian ${ }^{19}$. Hypatios jest jednym z twórców ortodoksyjnych wspólnot monastycznych Konstantynopola. Urodził się ok. 366 roku, zmarł zaś w 446 roku $^{20}$. Urodził się we Frygii $(\mathrm{VH} 1,1)$ w rodzinie chrześcijańskiej (VH 1,2). W młodości uciekł z domu rodzinnego i udał się do Tracji (VH 1,7-9), gdzie był najpierw pasterzem (VH 2,6), a następnie lektorem w miejscowym kościele (VH 2, 8-9). W wieku lat dwudziestu przystąpił do wspólnoty mniszej organizowanej przez ascetę Jonasza w Halmyrissos (VH 3 , $8-9)^{21}$. Ok. 400 roku opuścił klasztor Jonasza i wraz z dwoma towarzyszami zorganizował po azjatyckiej stronie Bosforu klasztor w Rufinianach (VH 8$)^{22}$. Hypatios był igumenem tego klasztoru, $\mathrm{z}$ wyjątkiem okresu konfliktu $\mathrm{z}$ ascetą Tymoteuszem (VH 9,1-10), aż do swej śmierci ${ }^{23}$.

Ponieważ Vita Hypatii powstało w niedługim czasie po śmierci tytułowego bohatera, stąd jest dla nas jednym z najważniejszych źródeł do badania początków monastycyzmu konstantynopolitańskiego i jego specyfiki ${ }^{24}$. Próbując za-

${ }^{17}$ Przy omawianiu niniejszego zagadnienia posługujemy się wydaniem: Callinicos, Vie d'Hypatios $(=\mathrm{VH})$. Introduction, texte critique, traduction et notes par G.J.M. Bartelink, SCh 177, Paris 1971.

18 Por. G.J.M. Bartelink, Introduction, SCh 177, s. 11-12 oraz G. Dagron, Les moines en ville. Le monachisme á Constantinople jusqu'au Concile de Chalcédoine (451), „Travaux et Mémoires” $4(1970)$ s. 231.

19 W kwestii autorstwa Vita Hypatii zob. G.J.M. Bartelink, Introduction, SCh 177, s. 9-11.

${ }^{20}$ Hypatios zmarł w wieku lat osiemdziesięciu ( $V H$ 51).

${ }^{21}$ Kallinikos podaje, że klasztor w Halmyrrisos był położony w Tracji. Jedyne zlokalizowane miejsce o tej nazwie znajduje się w Dobrudży w delcie Dunaju (dziś Dunavătu de Jos) por. E. Popescu, Inscriptiile greceşti şi latine din secolele $I V$-XIII descoperite în România, Bucureşti 1976, s. 180.

22 W kwestii klasztoru w Rufinianach zob. J. Pargoire, Rufinianes, „Byzantinische Zeitschrift” 8(1899) 429-477 oraz G. Dagron, Les moines en ville, s. 229-276.

${ }^{23}$ O Hypatiosie zob. też E. Wölfle, Hypatios. Leben und Bedeutung des Abtes von Ruphiniane, Frankfurt a. M. - Bern - New York 1986.

24 O początkach monastycyzmu konstantynopolitańskiego zob. przede wszystkim G. Dagron, Les moines en ville, passim; J. Pargoire, Rufinianes, passim, a także M. Kanior, Historia monas- 
rysować jeden z elementów owej specyfiki porównamy cechy wyróżniające ideał świętego męża z opisem Hypatiosa, jaki znajdujemy na kartach dzieła Kallinikosa.

Kallinikos, przedstawiając w swym dziele postać Hypatiosa, ukazuje go z całą pewnością jako świętego. Już w prologu autor pisze, że mnisi prosili go o opisanie życia Hypatiosa, który jest "we wspólnocie świętych". ${ }^{25}$. Wielokrotnie też nazywa go później świętym ${ }^{26}$. Nie oznacza to jednak automatycznie, że ideał świętości reprezentowany przez Hypatiosa pokrywa się z tym, który jest właściwy dla świętego męża. W tym celu skonfrontujemy cechy świętego męża z informacjami zawartymi w Vita Hypatii. Trzeba oczywiście zaznaczyć, że każdy święty z osobna ma pewne cechy, zespół zachowań i sposobów bycia różniący go od pozostałych. Każdy jest indywidualnością, często niepowtarzalną. Byli nawet święci tak dalece odbiegający od ideału, jak na przykład ,święci głupcy" - osoby, które służyły Bogu przyjmując maskę szaleństwa czy głupoty ${ }^{27}$. Jednak większość Żywotów posiada charakterystyczne elementy, łączące swych bohaterów tak dalece, że możemy mówić o pewnym powszechnym ideale świętego męża.

1. Odejście ze społeczeństwa. Cechą wspólną wszystkich albo większości bohaterów Żywotów jest opuszczenie przez nich społeczeństwa wraz z całym skomplikowanym systemem zależności i więzi społecznych ${ }^{28}$. Święty mąż udaje się na pustynię lub na górę (albo na słup, do opuszczonej groty, czy niewykorzystywanej cysterny), by w ten widzialny sposób zerwać ze światem, w którym żył dotychczas. Nie znaczy to, że święty jest zupełnie wyizolowany ze społeczeństwa - to społeczeństwo odkrywa świętego i do niego przychodzi. Nie jest on jednak już wtedy częścią składową tej ludzkiej wspólnoty, ale kimś obcym² ${ }^{29}$. Obcym nawet dla lokalnej wspólnoty kościelnej, gdyż rzadko się zdarza, by

tycyzmu chrześcijańskiego, tom 1: Starożytność, Kraków 1993, s. 139-140 oraz G. Dagron, Naissance d'une capitale, Constantinople et ses institutions de 330 à 451, Paris 1974, s. 509-517 (późniejsza, skrócona wersja cytowanego przez nas artykułu); C. Mango, Historia Bizancjum, thum. M. Dąbrowska, Gdańsk 1997, s. 111-112; H. Delehaye, Byzantine Monasticism, w: Byzantium, An Introduction to East Roman Civilization, ed. N.H. Baynes - H.St.L.B. Moss, Oxford 1948, s. 144; A.H.M. Jones, The Later Roman Empire 284-602. A Social, Economic and Administative Survey, Baltimore 1986, s. 930. W kwestii położenia poszczególnych klasztorów Konstantynopola zob. R. Janin, Les églises et les monastéres, Paris 1953.

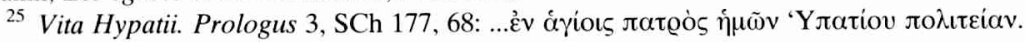

${ }^{26}$ Dodajmy, że Hypatios jest świętym Kościoła Prawosławnego, a jego wspomnienie przypada 15 marca, por. A.P. Rudakov, Ocherki vizantiyskoy kultury po dannym grecheskoy agiografii, Sankt-Petersburg 1997 (reprint wyd. Moskwa 1917), s. 229.

${ }^{27}$ Por. L. Rydén, The Holy Fool, w: The Byzantine Saint, s. 106-113.

${ }^{28}$ Por. R. Browning, The 'Low Level' Saint's Life, s. 118-121; w poniższym fragmencie często będziemy się posiłkować niektórymi ustaleniami Browninga zawartymi w tym artykule.

29 Akcentuje to zwłaszcza P. Brown, por. The Rise, s. 91. 
święty mąż był wyświęcony na kapłana, a jeżeli tak, to najczęściej wbrew własnej woli ${ }^{30}$. Tak więc święty może żyć w społeczeństwie, nawet w zatłoczonym mieście, nie staje się jednak w pełni jego częścią składową.

W dziele Kallinikosa znajdujemy stosunkowo niewiele podobnych informacji, chociaż, oczywiście, takie występują. Już w pierwszym rozdziale Vita $H y$ patii czytamy, że w młodości Hypatios opuścił dom rodzinny i krainę, w której żył, by udać się do odległej Tracji1 ${ }^{31}$, gdzie z kolei porzucił funkcję lektora i karierę duchowną, by wstąpić do klasztoru Jonasza ${ }^{32}$. Informacje te jednak wcale nie oznaczają zupełnego oderwania się od społeczeństwa - udanie się do Tracji jest raczej ucieczką z rodzinnego domu niż świadomym wyborem odległej krainy, gdzie mógłby się doskonalić. Natomiast, nawet będąc w klasztorze Halmyrissos Hypatios opiekował się chorymi, których odnajdywał, opuszczając nieraz mury klasztoru i udając się na długą wędrówkę po okolicznych polach i drogach, skąd sprowadzał do klasztoru ludzi chorych ${ }^{33}$.

Mimo to, Hypatios nie był w stanie dłużej przebywać w samym Konstantynopolu, gdyż, jak sam mówił: „Byłem przyzwyczajony mieszkać w górach, a nie w mieście"34. Opuścił więc stolicę i udał się na azjatycki brzeg Bosforu w poszukiwaniu góry lub groty, pozostając w końcu wraz ze swymi towarzyszami w opuszczonej fundacji Rufina ${ }^{35}$. W dalszym fragmencie Kallinikos informuje nas, że święty nie opuszczał Rufinian, prócz udawania się na coniedzielną Eucharystię, którą sprawował w kościele Świętych Apostołów ${ }^{36}$. Powyższe informacje oznaczałyby, że igumen Rufinian w murach swojego klasztoru odnalazł miejsce swojego wyłączenia się ze społeczeństwa.

Tymczasem w dziele Kallinikosa znajdujemy wiele fragmentów, które zdają się być sprzeczne z tą ostatnią informacją. Wielokrotnie bowiem spotykamy Hypatiosa właśnie $w$ podróży, nie tylko w sprawach związanych $\mathrm{z}$ posługą kapłańską. Możemy tu wspomnieć chociażby o jego aktywnej działalności misyjnej w Bitynii ${ }^{37}$, o jego obecności w Chalcedonie związanej z planowany-

${ }^{30}$ Por. chociażby opis wyświęcenia na kapłana Salamanesa, który był tego nieświadomy (Theodoretus, Historia religiosa 19,2) czy próbę wyświęcenia Marcjana (tamże 3, 11). Bardziej drastyczny opis znajdujemy u Palladiusza, gdzie Ammonios okalecza się, by nie przyjąć święceń biskupich (Palladius, Historia Lausiaca 11,1-3). Por. też B. Degórski, Kapłaństwo w monastycyzmie starożytnym, VoxP 13-15(1993-1995) t. 24-29, 233-245.

31 Por. $V H 1,9$.

32 Por. $V H 3,8$.

33 Por. $V H$ 4, 5-7. Wyraźną informację o prowadzeniu przez świętego życia pustelniczego otrzymujemy dopiero w opisie konfliktu Hypatiosa z Tymoteuszem. Hypatios opuszczając na pewien czas wspólnotę w Rufinianach udał się do klasztoru Halmyrissos i poprosił tamtejszego igumena Jonasza, by ten odstąpił mu celę, w której mógłby wieść życie kontemplacyjne $(V H 9,10)$.

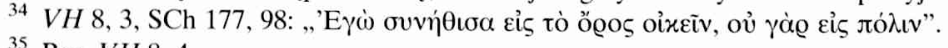

35 Por. $V H$ 8, 4.

36 Por. $V H 29,1$.

37 Por. VH 30, 1-2. 
mi Igrzyskami ${ }^{38}$, o jego wędrówce z mnichami koło góry Olimp ${ }^{39}$, czy o podróży do braci w głąb Bitynii ${ }^{40}$. To tylko kilka $\mathrm{z}$ wielu zamieszczonych w dziele przykładów dalszych podróży Hypatiosa.

Czy ta bardziej otwarta postawa Hypatiosa miała miejsce w związku z jego posługą kapłańską? Podobną odmianę spotykamy w Żywotach innych świętych męzów, którzy po otrzymaniu święceń kapłańskich czy też biskupich, zaczynali się aktywnie angażować w sprawy społeczności, do której zostali posłani, najczęściej stając na jej czele. Przykładem może tu być Jakub, biskup Nisibis, żyjący początkowo jako pustelnik w zaroślach i jaskini, który po swej ordynacji zaczął gorliwie opiekować się biedakami, stanął na czele obrońców miasta w czasie oblężenia perskiego, a nawet uczestniczył w Soborze w Nicei, gdzie stanowczo przeciwstawiał się poglądom Ariusza ${ }^{41}$. Czy postawa Hypatiosa jest w tym miejscu podobna? Wydaje nam się, że nie tylko samo kapłaństwo odegrało rolę w jego odmiennym od ideału stylu życia, ale także obowiązki związane ze staniem na czele wspólnoty mniszej, złożonej z kilkudziesięciu ludzi. Funkcja igumena w połączeniu z kapłaństwem powodowała, że ideał wyłączenia się ze społeczeństwa nie mógł być w pełni urzeczywistniony. Potwierdzają to zresztą słowa samego Hypatiosa, który przed swoją śmiercią zwierzył się swym braciom, że odkąd musiał się zajmować troskami braci i dbać o ich rozwój duchowy, czystość jego serca bardzo się skalała ${ }^{42}$. Następnie zaś kontynuowal: „Przedtem byłem wolny od trosk, bez przerwy zwracałem się w stronę Boga i czuwałem nad sobą". ${ }^{43}$ Sam więc dostrzegał niebezpieczeństwo związane z prowadzeniem klasztoru.

Kallinikos jednak nie zatrzymuje się tylko na stwierdzeniu faktu, że zaangażowanie w społeczność (mniszą czy ogólnoludzką) powoduje, iż życie kontemplacyjne jest mocno utrudnione (jeżeli nie uniemoźliwione), tylko kontynuuje swoją relację: jeden z uczniów Hypatiosa, po usłyszeniu jego słów wypowiedzianych ze smutkiem, odpowiedział igumenowi, że dawniej zbawiał wyłącznie siebie, teraz zaś ocala wielu ludzi, więc strata staje się zyskiem

${ }^{38}$ Por. $V H 33$.

${ }^{39}$ Por. $V H 46$.

${ }^{40}$ Por. $\mathrm{VH} 45$.

${ }^{41}$ Por. Theodoretus, Historia religiosa 1, 7-12. Podobnie Abraham, który po otrzymaniu biskupstwa Karrai nie zmienił swego ascetycznego sposobu życia, a nawet go zaostrzył, a zaangażował się gorliwie w przewodzenie społeczności wiernych tego miasta (tamże 17, 5-11). Nie zawsze jednak otrzymanie święceń było połączone z ponownym nawiązaniem więzi ze społecznością; inny święty mąż, Salamanes, który po otrzymaniu święceń (z czego nie zdawał sobie sprawy) kazał ponownie zabudować otwór do swojego domku, w którym żył z nikim nie rozmawiając i zachowując się tak, jakby całkowicie umarł dla świata (tamże 19).

${ }^{42}$ Por. $\mathrm{VH} \mathrm{48,35.}$

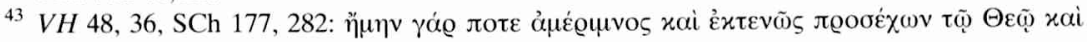

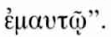


podwójnym ${ }^{44}$. Tak więc dla Kallinikosa święty powinien zadbać nie tylko o własny rozwój duchowy i stały kontakt z Bogiem, ale także o zbawienie innych. Ideał taki wymaga, oczywiście, stałego kontaktu z innymi ludźmi, mnichami i świeckimi. Stąd zupełne oderwanie się od społeczności ludzkich jest niecelowe, ponieważ uniemożliwia troskę o doskonalenie innych. Nie oznacza to, że w ogóle niewskazana jest jakakolwiek anachoreza (nie tylko w sensie przestrzennym). Sam Hypatios na przykład zamykał się w celi na okres Wielkiego Postu ${ }^{45}$. Biorąc pod uwagę całość Żywotu Hypatiosa możemy stwierdzić, że odosobnienie Hypatiosa jest tylko czasowe i przeważnie nie jest zupełne. Oznacza to dość istotną różnicę w stosunku do istniejącego w hagiografii ideału świętego męża czy może raczej korektę tego ideału. Korekta ta nie dotyczyła tylko odmiennego podejścia do praktyki oddzielenia się od społeczeństwa, lecz także innego spojrzenia na cele życia ascetycznego: w opisach innych świętych mężów dominuje chęć uświęcenia własnej osoby, podczas gdy tu widzimy inny cel - doskonalenie i zbawienie innych.

2. Uwolnienie się od zwyczajnych potrzeb. Drugą, ważną cechą ideału świętego męża jest uwolnienie się od zwyczajnych, ludzkich potrzeb, nieraz nawet elementarnych. Odrzuca on więc stosunki z kobietami, nie potrzebuje rodziny, często ją opuszcza, lub od niej ucieka. Święci najczęściej nie posiadają stałego schronienia i domu. Często zamieszkują groty, wydrążone drzewa czy też przebywają na odsłoniętej platformie słupa ${ }^{46}$. Święty może ograniczyć do minimum swoje pożywienie, a czasem w ogóle się go pozbawić. Najczęściej jednak zadawala się potrawami niegotowanymi, często też nie spożywa mię$\mathrm{sa}^{47}$. Trzeba jednak od razu zaznaczyć, że, jak już wyżej wspominaliśmy, w odróżnieniu od tendencji manichejskich, nie uważa rodziny, małżeństwa, jedzenia itd., za coś złego i demonicznego. To przecież święty mąż błogosławi niepłodnym kobietom czy też napełnia puste spichlerze ${ }^{48}$.

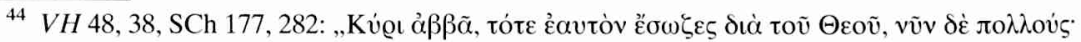

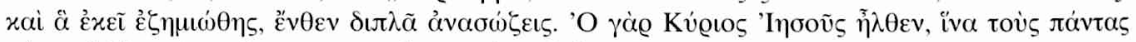
бஸ́øฺ ." Hypatios usłyszawszy te słowa ucieszył się w Panu.

45 Por. $V H 13,1 ; 28,25$. Trzeba jednak dodać, że Hypatios nie izolował się zupełnie od innych - przez małe okienko w drzwiach celi mówił do odwiedzających i umacniał ich. Surowe umartwienia w czasie Wielkiego Postu były czymś normalnym w życiu ascetów, por. chociażby Historia religiosa 26, 9, gdzie mamy do czynienia z opisem praktyk Symeona Stylity w czasie Wielkiego Postu.

${ }^{46}$ Byli też tacy, jak Jakub (Theodoretus, Historia religiosa 21, 5), którzy żyli pod gołym niebem.

${ }^{47}$ Por. Theodoretus, Historia religiosa 18, 1, gdzie Euzebiusz żywi się grochem i fasolą zmiękczonymi wodą, czy tamże 26, 9, gdzie ma miejsce opis słynnego postu Symeona Stylity.

${ }^{48}$ Por. tamże 14, 2, gdzie zapasy oliwy i ziarna Maisymasa, przeznaczone dla potrzebujących, są co dzień cudownie uzupełniane przez Boga, czy tamże 11, 4 gdzie Roman wyprasza dzieci dla niepłodnych kobiet. Ten ostatni problem jest ciekawy, gdyż święty mąż często unika wszelkiego 
Święty mąż może się również wyrzec snu. Święci stylici potrafili całe noce spędzać na modlitwie bez chwili spoczynku ${ }^{49}$. Zresztą konstrukcja platformy słupa najczęściej uniemożliwiała ułożenie ciała w pozycji leżącej, tak że odpoczywać mogli jedynie opierając się o rodzaj balustrady. Żywot świętego męża z Edessy podaje, że ów anonimowy święty spędzał całe noce na modlitwie ${ }^{50}$; podobnych relacji dostarczają nam także inne Żywoty. Święty nie potrzebuje też zazwyczaj ubrań, zwykle posiada jedynie jakiś lichy łach czy włosiennicę, a byli też tacy, którzy obywali się zupełnie bez odzieży ${ }^{51}$. Konfrontując powyższe informacje $z$ relacją Kallinikosa musimy stwierdzić, że asceza Hypatiosa należy do umiarkowanych, jej surowość nie jest w każdym razie stałą cechą świętego.

Pewne ograniczenia pożywienia, o jakich dowiadujemy się w Żywocie Hypatiosa, późniejszy igumen Rufinian narzucił sobie już w młodości. Nie pijał wina zgorszony złym przykładem kleru wiejskiego ${ }^{52}$, zasadę tę utrzymał aż do późnej starości, kiedy to ze względu na wiek pił niewielkie ilości tego

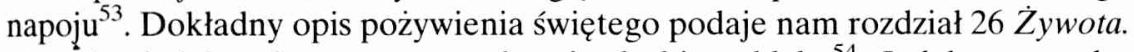
Hypatios jadał suche warzywa, sałatę i odrobinę chleba ${ }^{54}$. Jadał zawsze dopiero po dziewiątej godzinie dnia, a więc już po południu, a często nawet później ${ }^{55}$. Posiłek swój ograniczał dodatkowo w czasie Wielkiego Postu, kiedy to zamknięty w celi jadał chleb co drugi dzień ${ }^{56}$. Często zresztą zaostrzał i ten sposób odżywiania się, gdyż po skończeniu Wielkiego Postu bracia znajdowali $w$ jego celi chleb ułożony $w \operatorname{stos}^{57}$. Z pozostałych informacji zamieszczonych w Żywocie, a dotyczących pożywienia świętego, dowiadujemy się, że w czasie początkowych, trudnych lat w Rufinianach, na początku V wieku, często nie jadał po to, by pozostali dwaj bracia mogli się posilić ${ }^{58}$. Poza tą informacją mamy do czynienia jeszcze $\mathrm{z}$ opisem surowych postów Hypatiosa w klasztorze Jonasza. I tak, często pościł zupełnie przez pięć dni, innym zaś razem nie pił wcale przez pięćdziesiąt dni, aż popękały mu wargi, a żołądek

kontaktu z kobietami: por. Evagrius Scholasticus, Historia ecclesiastica I 14, PG 86/2, 2461B, thum. S. Kazikowski: Ewagriusz Scholastyk, Historia Kościoła, Warszawa 1990, s. 27, gdzie jest wzmianka, że do kolumny Symeona Stylity nie mają dostępu kobiety. Zob. także E. Wipszycka, Wierni u stóp Symeona Stupnika, s. 97-98.

${ }^{49}$ Por. Theodoretus, Historia religiosa 26, 22.

${ }^{50}$ Por. H. J. W. Drijvers, Hellenistic and Oriental Origins, s. 27.

51 Por. R. Browning, The 'Low Level' Saint's Life, s. 120.

52 Por. $V H 2,10$.

53 Por. $V H 26,1$.

${ }^{54}$ Por. $V H$ 26, 1.

55 Por. $V H 26,2$.

${ }^{56}$ Por. $V H 13,1$ oraz $26,2$.

57 Por. $V H 14,5$.

${ }^{58}$ Por. $V H 17,1-8$. Hypatios udawał, że jadł, dlatego, by wystarczyło chleba dla pozostałych braci i gościa. 
jego stał się jak skóra ${ }^{59}$. Ostatnie miejsce dotyczące pożywienia świętego informuje nas dość ogólnikowo, że górował nad innymi braćmi z klasztoru Halmyrissos między innymi w postach ${ }^{60}$. Interesujący jest fakt, że opis surowych postów Hypatiosa dotyczy wczesnego okresu jego ascetycznej drogi, który miał miejsce w klasztorze Jonasza w Tracji. Później mamy już do czynienia z opisem ograniczonego pożywienia, lecz bez ekstremalnych postów. Nawet umartwienia świętego w czasie Wielkiego Postu nie można porównywać, na przykład, z podobnymi umartwieniami Symeona Stylity ${ }^{61}$. Wydaje się jednak, że umartwienia Hypatiosa bardziej odpowiadały idei postu nakreślonej przez mistrzów życia duchowego niż świętych mężów stosujących, podobnie do wspomnianego Symeona, ekstremalne umartwienia: umożliwiały one opanowanie ciała i jego potrzeb, nie groziły natomiast poważnym uszkodzeniem zdrowia świętego ${ }^{62}$.

Jeśli chodzi o inne formy rezygnacji z normalnych potrzeb, to $\dot{Z} y w o t$ informuje między innymi, że Hypatios pogardzał pieniędzmi ${ }^{63}$, i że ograniczał swoje kontakty z kobietami do tego stopnia, iż rzadko z nimi rozmawiał ${ }^{64}$. Tak więc można powiedzieć, że Kallinikos dostrzegał umartwienia Hypatiosa i jego rezygnację z normalnego sposobu życia głównie w dziedzinie ograniczenia pożywienia - inne zaś kwestie raczej go nie interesowały. Posty i nieurozmaicone pożywienie igumena Rufinian przy braku wzmianki o jakichś innych umartwieniach (z wyjątkiem zamknięcia w celi w czasie Wielkiego Postu) różnią Hypatiosa od ideału świętego męża, zwłaszcza syryjskiego. Ta umiarkowana asceza widoczna jest również w naukach świętego, który głosił, że jedzenie i picie nie są czymś złym, a złem jest jedynie łakomstwo. Dlatego nie głosił wstrzymywania się od pożywienia, ale wzywał do odżywiania ciała pokarmem mało zróżnicowanym $^{65}$. „Albowiem jarzyna, groch i pszenica są niezbędne do życia, do podpory duszy i siły dla dobrej pracy"66. Walka z łakomstwem jest jednak konieczna, ponieważ z niego pochodzi wszelkie zło, a wstrzemięźliwość opa-

${ }^{59}$ Por. $V H$ 5, 1-2. 8.

${ }^{60}$ Por. $V H 3,12$.

61 Theodoretus, Historia religiosa 26, 9: Symeon Stylita miał przez czterdzieści dni nie przyjmować w ogóle posiłków.

62 Por. Evagrius Ponticus, De malignis cogitationibus 1, gdzie nadmierne jedzenie jest potraktowane jako pierwszy etap na drodze ku nieczystości i innym grzechom. Święci asceci nie potępiali ciała jako takiego, ale starali się poskromić namiętności, por. Apophthegmata Patrum, Abba Pojmen, ed. P. B. Paschos 184 , gdzie abba Pojmen na pytanie czemu polewa sobie nogi, gdy inni praktykują surowość i doświadczają swoje ciała, odpowiedział, że uczono go zabijać namiętności, a nie ciało.

63 Por. $V H 34,1$.

64 Por. $\mathrm{VH} 35,6$.

65 Por. $V H$ 24, 64-81.

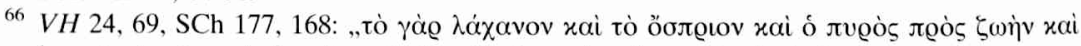

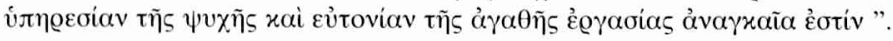


nowuje żądze ciała i zachowuje czysty umysł oraz dostarcza wielu dóbr ${ }^{67}$. Mimo tego, że Kallinikos w swym dziele nie kładzie zbyt dużego nacisku na rezygnację ze zwyczajnych potrzeb (co może wynikać z przyjęcia tego za rzecz oczywistą), to wstrzymywanie się od pożywienia zróżnicowanego oraz ilościowe ograniczanie swego posiłku jest dla niego cechą człowieka świętego, który nie odczuwa negatywnie tych umartwień, jako, że „prawdziwie święci żywią się potrawami wspaniałymi korzystając ze stołu boskiego i duchowego we wnętrzu człowieka". 68

3. Nadludzkie predyspozycje. Odejście ze społeczeństwa i uwolnienie się od zwyczajnych potrzeb odróżniają świętego męża od przeciętnego człowieka i wyróżniają go w społeczeństwie. Często też powodowały one, iż współcześni zadawali sobie pytanie, czy rzeczywiście święci są zwykłymi ludźmi, czy może aniołami zesłanymi $z$ nieba ${ }^{69}$. Wrażenie to pogłębiały dodatkowo nadludzkie predyspozycje świętego, zarówno duchowe, jak i fizyczne. By móc wyrzec się wymienionych przez nas potrzeb musi on posiadać niezwykłą wytrzymałość i odporność, a czasem, zdaje się, że nawet niezniszczalność. Większość świętych cieszyła się często długowiecznością ${ }^{70}$. Święty mąż posiada zdolność bilokacji, ma moc stawania się niewidzialnym ${ }^{71}$, a nawet potrafi przepowiadać przyszłość i to niekiedy dotyczącą losów Cesarstwa ${ }^{72}$. Może mieć także prorocze sny lub wizje, w których może oglądać rzeczy odległe, a nawet sferę boskości. Potrafi także przenikać ludzkie myśli i uczucia ${ }^{73}$.

Dostęp do świata duchowego powoduje nieunikniony konflikt $\mathrm{z}$ siłami demonicznymi. Stąd też częsta walka świętego z demonami i siłami zła. Ze wszystkich tych zmagań jednak, wzorem Antoniego, święty wychodzi zawsze

${ }^{67}$ Por. $V H$ 24, 62-64. Chociaż wedle tej nauki łakomstwo jest największym niebezpieczeństwem, a wstrzemięźliwość cnotą główną, to w innych fragmentach położony jest nacisk przede wszystkim na niebezpieczeństwo pychy, która może prowadzić do upadku nawet największych ascetów, zaś pokora jest dlatego cnotą największą, por. $V H 24,90$ oraz 42, 33-34.

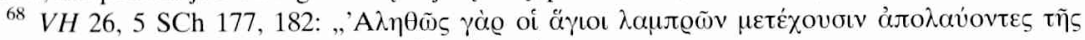

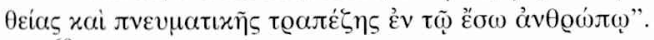

${ }^{69} \mathrm{Z}$ dzieła Teodoreta możemy się dowiedzieć, że współcześni świętym ludzie zastanawiali się, jaka jest prawdziwa natura tych wielkich osobistości. Do Symeona Stylity z podobną wątpliwością zwrócił się nawet diakon (Historia religiosa 26, 23 i 6,8) - wątpliwości, czy Symeon Starszy nie jest „zwodniczym demonem”; zob. także Palladius, Historia Lausiaca 18, 12-16, gdzie mnisi pachomiańscy proszą Pachomiusza, by ten wygnal z klasztoru Makarego z Aleksandrii, ,człowieka bez ciała”, po jego wielkopostnej surowej ascezie; zob. też E. Wipszycka, Wierni u stóp Symeona Stupnika, s. 99-100.

${ }^{70}$ Daniel Stylita żył 84 lata, Lazaros Galeziota 86, Teodulos Stylita 90, Łukasz Stylita miał ponad 100 lat, por. R. Browning, The 'Low Level' Saint's Life, s. 123.

${ }^{71}$ Por. Theodoretus, Historia religiosa 12,6 , gdzie Zenon staje się niewidzialnym dla Izaurów.

${ }^{72}$ Por. tamże, 2, 14, gdzie Julian Saba przepowiada śmierć cesarza Juliana.

73 Por. tamże 21, 17-22, gdzie Jakub słyszy głos z nieba i ma widzenie patriarchy Jakuba i Jana Chrzciciela. 
zwycięsko, a jego moc egzorcyzmowania umożliwia mu panowanie nad diab$ł^{7} \mathrm{~m}^{74}$. Potrafi równocześnie jednać grzeszników z Bogiem - ma więc również dostęp do Królestwa Niebieskiego, gdzie jest niejako adwokatem grzesznego człowieka $^{75}$.

Jednak najbardziej charakterystyczną cechą świętego męża jest jego zdolność leczenia. Święty panuje nad każdą chorobą bez względu na to, czy jest to gorączka czy paraliz ${ }^{76}$. Uzdrawiającą moc ma przede wszystkim modlitwa świętego, która może uzdrawiać nawet na odległość. Jednakże tę cudowną moc posiadają również frędzle czy inne kawałki jego odzienia ${ }^{77}$. Wszelkie opisy uzdrowień zajmują przodujące miejsce w Żywotach: musiały więc być one czymś, do czego przywiązywano wagę największą i co najczęściej przyciągało do świętego rzesze ludności. Ekstremalnym przypadkiem uzdrowień jest wskrzeszenie zmarłych ${ }^{78}$.

Nie tylko jednak ciało ludzkie i świat duchowy jest przez świętego kontrolowany, panuje on także nad siłami natury. Potrafi nie tylko zsyłać plagi, ale także ratować ludność przed suszami czy powodziami ${ }^{79}$. Ma więc dostęp do wszelkich sfer życia ludzkiego i ma nad nimi władzę.

$\mathrm{W}$ przeciwieństwie do poprzednich cech świętego męża, $\mathrm{z}$ nadludzkimi predyspozycjami Hypatiosa mamy do czynienia w Vita Hypatii bardzo często. W zasadzie cała część dzieła, obejmująca rozdziały od 14 do 48 , składa się bądź z nauk Hypatiosa bądź właśnie $\mathrm{z}$ opisu cudownych wydarzeń, jakie miały miejsce za przyczyną świętego.

Chociaż pierwsza część narratio hagiographica zawiera niezbyt wiele opisów cudownych sytuacji, to nadludzkie predyspozycje uwidoczniły się już w młodości Hypatiosa. Po ucieczce z domu rodzinnego, gdy przebywał z podróżującymi do Tracji, demony nocne nie robiły ludziom nic złego, gdyż były świadome, że znajduje się wśród nich dziecko, przeciw któremu niewiele mogą zdziałać ${ }^{80}$.

Pierwszym darem, jaki otrzymał Hypatios w czasie swego pobytu w klasztorze Jonasza, był dar uzdrawiania. Już w czasie swej opieki nad chorymi

${ }^{74}$ Por. VA 5-7, 9-10; a także Theodoretus, Historia religiosa 3, 9, gdzie Marcjan uwalnia z opętania dziewczynę lub tamże 28,2 , gdzie Talelajos nie daje się zwieść przez demony i śmieje się z ich podstępów; zob. też D.N. Bell, Shenoute the Great: The Struggle with Satan, „Cistercian Studies Quarterly" 21(1986) 177-185.

${ }^{75}$ Por. P. Brown, The Rise, s. 97-98.

${ }^{76}$ Por. Theodoretus, Historia religiosa 16,2, gdzie Maron leczy m. in. gorączkę i tamże 26, 17, gdzie Symeon Stylita uzdrawia paralityka.

77 Por. tamże 9, 15 i 21, 16, gdzie jest mowa o uzdrawiającej mocy szat świętego męża, a także E. Wipszycka, Wierni u stóp Symeona Stupnika, s. 101.

${ }^{78}$ Por. Theodoretus, Historia religiosa 7, 2-3, gdzie Palladiusz wskrzesza zmarłego, by ten wskazał swego zabójcę.

${ }^{79}$ Por. tamże 6, 5, gdzie Symeon Starszy gasi pożar dzięki swej modlitwie.

${ }^{80}$ Por. $V H 2,2$. 
swoim zaangażowaniem i modlitwą przyczyniał się do ich wyleczenia ${ }^{81}$, zaś po cudownym uzdrowieniu człowieka sparaliżowanego, dla mnichów, wśród których przebywał, stało się oczywistym, że „Bóg dał mu łaskę uzdrawiania”. ${ }^{82}$ Swój dar potwierdzał wielokrotnie, przyczyniając się między innymi do polepszenia zdrowia Jonasza ${ }^{83}$. Z dalszych rozdziałów Vita Hypatii dowiadujemy się, że Hypatios przyczynił się do uzdrowienia sługi Urbicjusza ${ }^{84}$, pewnego niewidomego ${ }^{85}$, bezpłodnej żony lektora z kościoła Świętych Apostołów $^{86}$, a także kamieniarza, któremu został przywrócony wzrok ${ }^{87}$. W rozdziale $36 \dot{Z}$ ywota autor wylicza schorzenia, z których za przyczyną świętego ludzie zostawali uzdrowieni, a byli to chromi, paralitycy, niewidomi i chorzy na inne choroby ${ }^{88}$. Interwencje Hypatiosa nie ograniczały się zresztą tylko do chorych ludzi, ale dotyczyły także i zwierząt: święty uzdrowił m.in. chorego byka $^{89}$.

Drugą nadludzką predyspozycją, jaką posiadał Hypatios, była zdolność do wyrzucania złych duchów czy w ogóle panowania nad szatanem. Cecha ta łączy się niejako z poprzednią - Hypatios uzdrawiał ludzi nie tylko ze zwyczajnych chorób, ale także $\mathrm{z}$ opętania (opętanie zresztą najczęściej sprowadzało na człowieka gwałtowne pogorszenie jego stanu zdrowia). Walka z demonami jest niezwykle istotnym elementem związanym ze świętością igumena Rufinian, dlatego też znajdujemy ją często na kartach Vita Hypatii ${ }^{90}$. Dowiadujemy się więc, że święty uzdrowił opętanego człowieka imieniem Agatangelos ${ }^{91}$, zaś w rozdziale 40 dzieła, że uwolnił kilka osób z opętania, a były to: pewna

${ }^{81}$ Por. $\mathrm{VH}$ 4, 7-8.

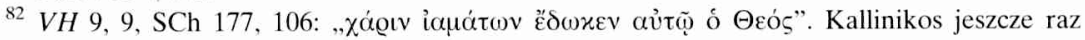
informuje nas o otrzymaniu przez Hypatiosa tego charyzmatu, por. 12, 2. O uzdrowieniu sparaliżowanego zob. $V H$, 1-3.

${ }^{83}$ Por. $V H 10,6$.

${ }^{84}$ Por. $V H 15,1-2$.

${ }^{85}$ Por. $V H$ 22, 7-9. Opis tego uzdrowienia jest podobny do ewangelicznego uzdrowienia niewidomego przez Jezusa - niewidomy prosi świętego, by ten, podobnie jak Chrystus niewidomemu, przywrócił mu wzrok za pomocą śliny, por. Mk 7, 33 .

${ }^{86}$ Por. $V H 28,35-36$. Tu z kolei mamy do czynienia z proroctwem Hypatiosa, które jest wprost wzorowane na słowach Archanioła Gabriela w czasie zwiastowania Maryi, por. Łk 1, 31.

${ }^{87}$ Por. $\mathrm{VH} \mathrm{44,} \mathrm{28-30.}$

88 Por. $V H 36,6$.

${ }^{89}$ Por. VH 22, 21. Hypatios uzdrowił zwierzę poprzez pocieranie jego języka solą, modlitwę i znak krzyża.

${ }^{90}$ Kallinikos w opisach zmagań Hypatiosa $\mathrm{z}$ demonami postępuje przede wszystkim za Atanazym i jego Żywotem Antoniego, gdzie walka z szatanem zajmuje pierwszorzędne miejsce, por. VA 5-6. 8-9. 11. 13. 21-42. 51-53. 65. 71. 88; zob. także P. Alvarez, Demon Stories in the Life of Antony by Athanasius, „Cistercian Studies Quarterly” 23(1988) 101-118; N.H.St. Baynes, Anthony and the Demons, ,Journal of Egyptian Archeology” 40(1954) 7-10.

${ }^{91}$ Por. $V H$ 22, 10-13. Hypatios uczynił nad nim znak krzyża, modlił się za niego i namaszczał go świętymi olejami. 
nieznana $\mathrm{z}$ imienia kobieta ${ }^{92}$, Aleksander ${ }^{93}$ i Stefan ${ }^{94}$. Z dalszego rozdziału dowiadujemy się, że dzięki modlitwom świętego uzdrowiona została też cubicularia Eufemia, która również była dręczona przez złego ducha ${ }^{95}$. Powyższe przypadki uzdrowień z opętania nie są zapewne wszystkimi.

Z innego rozdziału Żywota Hypatiosa dowiadujemy się, że możność wypędzania złych duchów była charyzmatem od Boga, który „dawał mu łaskę uzdrawiania, tak, że poprzez modlitwę i pieczęć Chrystusa zwalczał najgroźniejsze demony". ${ }^{96}$ Walka z demonami nie ograniczała się tylko do ich wypędzania z opętanych, ale przybierała także formę bezpośrednich zmagań duchowych. Już w rozdziale $15 \dot{Z}$ ywota mamy do czynienia z mistyczną rozmową Hypatiosa z szatanem, który ubrany w piękne szaty objawił się świętemu, by toczyć z nim spór. Nieprzejednana postawa świętego i moc jego modlitwy spowodowały, że diabeł znikną ${ }^{97}$. Od tego momentu mamy wielokrotnie do czynienia z kontaktem mistycznym pomiędzy demonami a świętym, który pozyskał laskę rozpoznawania duchów ${ }^{98}$. Demony toczyły z nim spór między innymi o chorego stajennego, którego własnymi rękami leczył Hypatios, a który to stajenny cudzołożył i przyjął świętokradczo Komunię świętą. Stąd też złe duchy domagały się duszy tego człowieka uważając, że taki grzesznik nie może być uzdrowiony ${ }^{99}$.

Kontakty świętego ze złymi duchami przybierały często także postać rzeczywistej walki. W czasie konfliktu Hypatiosa z człowiekiem uprawiającym magię, który zatruwał życie w klasztorze Eumathiosa, igumen Rufinian stoczył prawdziwą walkę z demonami, które zaatakowały go pod postacią wielbłądów z szyjami i głowami wężowymi. W tej walce Hypatios był wspierany przez anioła Bożego, dzięki któremu został cudownie uratowany z niebezpieczeństwa. W rozdziale tym Kallinikos wykazał też, że jego mistrz nie tylko pokonał złe duchy, ale nawet miał możność im rozkazywać - skierował je bowiem, by dręczyły owego człowieka, który je zesłał na świętego ${ }^{100}$. Z kolei w późniejszym

92 Por. $V H 40,1-4$. Kobieta została uzdrowiona przez położenie rąk świętego.

93 Por. $V H$ 40, 5-7. Uzdrowienie dzięki modlitwie Hypatiosa.

94 Por. $V H$ 40, 8-16. Uzdrowiony również dzięki modlitwie.

95 Por. $V H$ 44, 1-7.

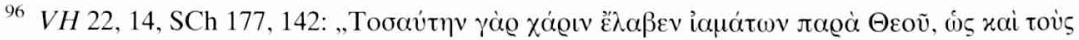

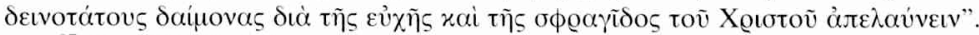

97 Por. $V H 15,3-8$.

98 Por. chociażby VH 28, 3-6, gdzie Hypatios w mistyczny sposób widzi demony wokól kobiety praktykującej magię. We fragmencie tym czytamy, że złe duchy odstępują od chorego człowieka, $\mathrm{z}$ uwagi na moc świętego.

99 Por. $V H$ 28, 10-13. Fragment ten jest bardzo nietypowy, przede wszystkim dlatego, że Hypatios uznał argumenty demonów, które oskarżały stajennego. I choć nie wierzył im w zupełności, bowiem czekał na potwierdzenie ich słów przez chorego, to jednak pozwalał, by złe duchy skutecznie oskarżały człowieka, zgodził się na triumf oskarżyciela i oddał stajennego w jego ręce.

${ }^{100}$ Por. $V H$ 28, 19-23. 
rozdziale jest mowa o tym, że modlitwa Hypatiosa sprawiła, iż olbrzymia postać Artemidy znikła $^{101}$.

Dostęp świętego w sferę pozacielesną nie ograniczał się wyłącznie do umiejętności rozpoznawania duchów. Kolejną bowiem jego nadludzką predyspozycją była łaska przepowiadania przyszłości i doznawania proroczych wizji. Już z początkowych rozdziałów dowiadujemy się, że Hypatiosowi objawionych zostało wiele tajemnic, o których nie chciał mówić ${ }^{102}$. Słowa te są wielokrotnie potwierdzone w późniejszych rozdziałach Żywota, gdzie świętemu zostało w cudowny sposób objawione miejsce pod nową studnię ${ }^{103}$, a także objawiony przyszły nieurodzaj, co umożliwiło mnichom zgromadzenie odpowiednich zapasów na przetrwanie trudnego okresu ${ }^{104}$. W czasie konfliktu świętego z Nestoriuszem, Hypatios miał wizję, która dotyczyła przyszłych losów biskupa Konstantynopola $^{105}$. Widzenie duchowe umożliwiło mu także wyczucie zapachu szatańskiego u pewnego Antiocheńczyka, trudniącego się praktykami magicznymi ${ }^{106}$. W kolejnym rozdziale jest mowa o tym, że igumen Rufinian miał wizję śmierci Elpidiosa ${ }^{107}$. Wreszcie, na łożu śmierci, Hypatios miał wizję wielu tragedii, jakie miały nastąpić po jego śmierci ${ }^{108}$. Oczywiście, wszystkie z powyższych prorockich wizji Hypatiosa sprawdziły się w przyszłości.

Natomiast nie widzimy na ogół w dziele Kallinikosa, by Hypatios posiadał zdolność panowania nad siłami natury. Sytuacja taka pojawia się w Żywocie tylko raz - w czasie wędrówki igumena i jego mnichów przez górę Olimp, kiedy to dzięki modlitwie świętego, w cudowny sposób ominęła ich nadciągająca burza $^{109}$. Nie mamy jednak więcej do czynienia z podobnymi opisami.

Do powyższych cech charakteryzujących Hypatiosa możemy dołączyć jeszcze i to, że nawet jego eulogie zawierały w sobie część jego cudownej mocy, o czym dowiadujemy się z rozdziału 38, który poświęcony jest właśnie w całości eulogiom świętego ${ }^{110}$. Dzięki nim m.in. niewolnik, który stracił oko, odzyskał

\footnotetext{
${ }^{101}$ Por. $V H 45,7-8$.

102 Por. $V H 14,1$.

103 Por. $V H$ 19, 4-6.

${ }^{104}$ Por. $V H 31,1-4$.
}

105 Hypatios miał dwie wizje dotyczące losów Nestoriusza. W pierwszej Nestoriusz został przedstawiony jako chwast, który zostanie wyrwany po trzech i pól dniach ( $V H 32,2)$. W drugiej natomiast święty Jan otrzymał polecenie od anioła, by ten przekonał cesarza do deponowania biskupa Konstantynopola ( $V H$ 32, 17-18).

${ }^{106}$ Por. $V H$ 43, 5.

107 Por. $\mathrm{VH} \mathrm{44,} 14$.

108 Por. $V H$ 50,2. Wedle wizji świętego po jego śmierci miał nastąpić gwałtowny grad, wielkie trzęsienie ziemi oraz najazd Hunów, por. $V H 52$.

${ }^{109}$ Por. $V H 46$.

${ }^{110}$ Eulogie, o których pisze w swym dziele Kallinikos, to kawałki błogosławionego chleba. W tej kwestii por. A. Stuiber, RACh VI 900-928; M. Pisarzak, Eulogia, EK IV 1302-1203; A.D. i Berardino, DPAC I 1281. 
$\mathrm{je}^{111}$. W innym przypadku ludzie opowiadali, że zostali uratowani dzięki posiadaniu eulogii Hypatiosa ${ }^{112}$, że ładunek człowieka, który je posiadał, został w cudowny sposób uratowany $z$ katastrofy morskiej ${ }^{113}$, a złe duchy przestały dręczyć konie z pobliskiej stajni dzięki temu, że na jej ścianie została zawieszona eulogia świętego ${ }^{114}$.

Ostatni wreszcie fragment, który podkreśla wyjątkowe cechy świętego, wskazuje na moc jego modlitwy. Dwaj bracia, którzy kopali studnię, szukając wody do nawadniania ogrodu, zostali do niej wciągnięci przez olbrzymi głaz, który był tak ciężki, że musiało go unieść ośmiu mężczyzn. Gdy bracia spadali, obecny przy studni Hypatios zawołał głośno: „Błogosławiony bądź, Panie”. Dzięki temu żaden $z$ braci nie zginął, a tylko jeden miał zmoczone ubranie ${ }^{115}$.

Przy omawianiu nadludzkich predyspozycji Hypatiosa musimy zastanowić się nad prawdziwym autorstwem dokonywanych przezeń cudów. Sam Hypatios mawiał: „niech nikt nie myśli, że bez łaski Boga człowiek może uzdrawiać drugiego" 116 Tak więc Bóg jest w rzeczywistości prawdziwym autorem cudów Hypatiosa. Nie zawsze zresztą modlitwy i starania świętego o uzdrowienie człowieka były zwieńczone powodzeniem. W przypadku nieuczciwego Elpidiosa, Bóg zadecydował o jego śmierci, pomimo że igumen starał się polepszyć stan jego zdrowia ${ }^{117}$. Kallinikos zresztą w rozdziale $47 \dot{Z}$ ywota, który w pewien sposób kończy opisy licznych cudów świętego, podkreśla mocno ich Boże autorstwo: uzdrowienia i panowanie nad demonami, które opisuje w swym dziele, nie pochodziły od samego igumena, lecz od Boga, którego Hypatios wzywał. Bóg zaś przychylał się do jego modlitw, ponieważ Frygijczyk „kochał Go i wykonywał Jego rozkazy z wielkim oddaniem". ${ }^{118}$ Te słowa Kallinikosa mają podkreślać świętość pierwszego igumena Rufinian.

Nadludzkie predyspozycje, które przedstawiliśmy, są jak najbardziej zgodne $\mathrm{z}$ ideałem świętego męża. Łaska uzdrawiania i możność panowania nad

\footnotetext{
111 Por. $V H 38,1-5$.

112 Por. $V H 38,6$.

113 Por. $V H 38,7-9$
}

114 Por. VH 38, 10-12. Jest to dość charakterystyczna cecha świętości Hypatiosa. W innych źródlach natomiast spotykamy np. szaty świętych mężów, które posiadają cudowną moc, por. Theodoretus, Historia religiosa 9,15, gdzie szata Piotra Galaty posiada cudowne właściwości.

115 Por. $V H$ 40, 23-26.

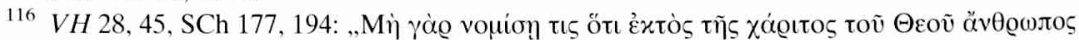

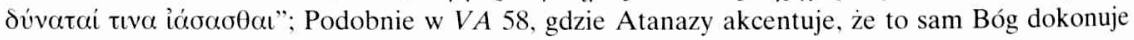
cudów, a nie Antoni, zob. także $V A 84$ - Antoni nie leczy swoją mocą, lecz Bożą.

117 Por. $V H 44,8-19$. Podobnie w VH 22, 5 czytamy, że chorzy, którymi zajmował się Hypatios, wracali w kilka dni do zdrowia, wtedy, gdy Bóg obdarzał ich swoją łaską. Podobnie u Atanazego, gdzie dowiadujemy się, że Bóg często, choć nie zawsze, wysłuchiwał Antoniego, który modlił się za chorych, por. $V A 56$.

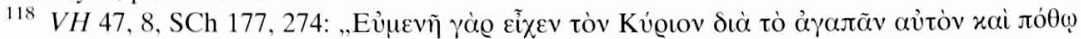

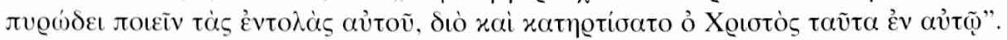


demonami są najczęściej występującymi cechami świętych mężów. Również zdolność proroczych wizji potwierdza ten ideał. Nie dostrzegamy wprawdzie, by święty panował nad siłami natury, i by cieszył się też długowiecznością - są to jednak cechy, które nie są nierozerwalnie związane z ideałem świętego męża, tak na przykład, jak właśnie panowanie nad złymi duchami. Nie bez przyczyny w cytowanym powyżej zdaniu z 47 rozdziału Żywota cuda dokonywane przez Hypatiosa są dla jego hagiografa dowodem świętości igumena.

4. Znaczenie społeczne. Panowanie świętego męża nad wszelkimi sferami, które dotyczyły poszczególnego człowieka i całych społeczności, określiło jego pozycję w społeczeństwie. Święty mąż staje się więc postacią, która potrafi odmienić zły los lub nieszczęście. Staje się jedyną pewną osobą, zwłaszcza dla ludzi zajmujących niską pozycję społeczną, by móc starać się o dostęp do innych instytucji, mogących pomóc w danym wypadku. Pewność świętego męża powoduje, że chociaż odchodzi on ze społeczeństwa, to społeczeństwo przychodzi do niego, obojętnie czy znajduje się on tuż za murami miasta, czy też droga do jego pustelni jest daleka. Władza świętego jest silniejsza nawet od władzy cesarskiej. To przecież on potrafi przewidzieć śmierć cesarza i losy całego Imperium. To on staje się doradcą wielkich tego świata, którzy pokornie stają u stóp jego kolumny. Stając poza społeczeństwem, nie opowiadając się za żadnym stronnictwem czy żadną klasą społeczną, święty staje się ostoją obiektywności i bezstronności, jest więc najlepszą osobą, do której można się zwracać o radę czy o pomoc w razie niesprawiedliwości sędziego. Pełni więc ogromnie ważną rolę społeczną, o której nie możemy zapominać starając się przeanalizować jego ideat ${ }^{119}$.

W dziele Kallinikosa znajdujemy również informacje o społecznym znaczeniu działalności Hypatiosa. Spotykamy w nim kilka informacji, z których dowiedzieć się możemy o znaczeniu jego i pozostałych mnichów klasztoru Rufinian dla okolicznej ludności. Święty duże znaczenie miał przywiązywać do opieki nad biednymi, których wspomagał. Kallinikos pisze, że za pośrednictwem igumena Pan przyodziewał nagich i karmił głodnych. Hypatios był dla sierot jak ojciec, a dla matek jak mąż, tak, że dla wszystkich oczywistym było, że kochał biednych ${ }^{120}$; żaden z nich nie opuszczał zakonu z pustymi rękoma. Co ważniejsze, Hypatios leczył tych, którzy byli zbyt ubodzy, by mogli leczyć się u lekarzy $^{121}$.

Tak więc społeczną działalność świętego można podzielić na opiekę nad chorymi, którzy nie mogli znaleźć pomocy u lekarzy czy też z innych powodów

119 Wpływ świętego męża na szerokie warstwy społeczeństwa był bardzo duży, por. S. Ashbrook Harvey, The Politicisation of the Byzantine Saint, w: The Byzantine Saint, s. 37.

120 Por. $V H$ 22, 1-2.

121 Por. $V H$ 22, 4-5. 
udawali się wprost do Hypatiosa oraz na wspomaganie ubogich. Do pierwszej kategorii, oprócz powyższego przykładu, trzeba zaliczyć też opiekę Hypatiosa nad chorymi w czasie jego pobytu w zakonie Jonasza w Halmyrissos ${ }^{122}$. Więcej informacji mamy na temat wspomagania ubogich, gdy dowiadujemy się między innymi, że igumen nakazał rozdanie zjadanego przez robaki zapasu zboża żebrakom ${ }^{123}$, lub gdy w innym miejscu czytamy, że rozdawał ubogim chleb ${ }^{124}$.

Prócz powyższych informacji tylko raz dowiadujemy się, że klasztor Rufinian miał społeczne znaczenie dla okolicznej ludności - świętemu został w cudowny sposób objawiony okres przyszłego głodu; zebrał więc odpowiednie zapasy z suszonych owoców i zboża, by móc przetrwać długi, trzyletni głód. W okresie tym okoliczna ludność była uzależniona od zapasów klasztornych, które umożliwiły jej przetrwanie, zwłaszcza w okresach zimowych. Kallinikos informuje nas, że w owym okresie przychodziło posilać się do Rufinian co najmniej pięćset osób ${ }^{125}$. Jest to jednak pojedyncza informacja i poza nią nie słyszymy, by okoliczna ludność była w jakiś szczególny sposób związana z klasztorem czy osobą samego Hypatiosa. Co więcej, w jednym z rozdziałów Żywota, który dotyczy mnichów Aleksandra Akoimety, obserwujemy wręcz wrogość uboższej ludności skierowaną przeciwko akoimetom i mnichom Hypatiosa $^{126}$. Podobnie w czasie konfliktu z biskupem Chalcedonu Eulaliosem o igrzyska ${ }^{127}$, igumenowi Rufinian udało się zmontować popierającą go grupę, która złożona była jedynie z mnichów - nie słyszymy, by należała do niej ludność świecka ${ }^{128}$. Nie był więc on, w świetle Żywota Hypatiosa, rzeczywistym przywódcą okolicznej ludności. Fakt ten różni go od ideału świętego męża, do którego często udawała się okoliczna społeczność po radę lub pomoc, tak jak to widzieliśmy w przypadku świętych mężów syryjskich.

Trudno odpowiedzieć na pytanie, czy Hypatios był takim świętym mężem, jakiego obraz nakreśliły największe źródła hagiograficzne. Inni święci mężowie nie byli identyczni, nie posiadali tych samych cech, nie byli odbiciem tego samego ideału. Każdy z nich posiadał jakąś indywidualną cechę odróżniającą go od pozostałych. Z drugiej strony igumen Rufinian w wielu miejscach różni się w dużym stopniu od nakreślonego ideału, a te cechy, które dzieli wspólnie

122 Por. $V H 4$.

123 Por. VH 20.

124 Por. $V H 18,1$.

125 Por. $V H$ 31, 3-6.

126 Por. $V H 41$.

127 Igrzyska planował Leontios, prefekt miasta Konstantynopola, por. VH 33, 1-5.

128 Por. VH 33, 9-10. 
z innymi świętymi mężami, przynależeć mogą w zasadzie do ogólnego ideału świętości: cudowna moc modlitwy, charyzmat uzdrawiania, panowanie nad demonami $^{129}$. Z pewnością w Vita Hypatii położony jest mniejszy nacisk na anachorezę, Hypatios jest bardziej zaangażowany w sprawy Kościoła powszechnego niż inni święci mężowie, praktykuje umiarkowaną ascezę, a jego znaczenie społeczne jest ograniczone.

Powyższe uwagi każą nam traktować Hypatiosa jako realizatora nieco odmiennego ideału świętości od tego, którego reprezentantem jest właśnie typowy święty mąż okresu późnego antyku. Ta odmienność wynika w dużym stopniu z odmienności kulturowej okolic Chalcedonu, innych warunków topograficznych, a przede wszystkim bliskości stolicy. To właśnie w bliskości dużego ośrodka miejskiego, jakim był stołeczny Konstantynopol, musimy szukać odpowiedzi na pytanie, co decydowało o specyfice świętości Hypatiosa. Stolica wymagała od świętego większej mobilności, większego zaangażowania się w sprawy świata i Kościoła. Właśnie z uwagi na tę bliskość stołecznego biskupstwa Konstantynopola, miasta które było centralnym miejscem sporów teologicznych, święty zmuszony był opowiedzieć się po którejś ze stron kontrowersji wstrząsających ówczesnym Kościołem, jak miało to miejsce w przypadku Nestoriusza. Bliskość stolicy to również bliskość ośrodków charytatywnych miasta, latwiejszy też dostęp do pałacu cesarskiego. Dlatego też święty nie odgrywa tu zbyt dużej roli jako przywódca okolicznej ludności, był bowiem dla ludności postacią o bardziej ograniczonych możliwościach interwencji niż możni i urzędnicy przebywający w stolicy.

Natomiast cuda czy nadludzkie predyspozycje Hypatiosa to cechy, jak już wspominaliśmy, doskonale pasujące do ideału świętego męża. Specyfika bliskości stolicy nie zmieniała bowiem faktu świętości igumena Rufinian, ani też nie wymuszała zmiany jej ,jakości”. Stąd też Hypatios czynił cuda, wypędzał złe duchy i przewidywał przyszłość, podobnie jak święci mężowie Syrii czy Ojcowie Pustyni. Ideał świętości ascety związanego licznymi więzami ze stolicą, który właśnie reprezentuje Hypatios, nie jest obecny we wcześniejszej literaturze hagiograficznej, z uwagi na brak Żywotów świętych związanych z tym terenem. To właśnie Vita Hypatii i późniejsze Żywoty tworzą ten ideał, który wyróżnia się własnymi cechami, odmiennymi od poprzednich ideałów.

${ }^{129}$ Por. R. Wiśniewski, Cuda i świętość, s. 282. 


\section{HYPATIOS, DER ERSTE IGUMEN VON RUPHINIANAI IM BERICHT DES KALLINIKOS UND DAS IDEAL DES HEILIGEN IN DER SPÄTANTIKEN GESELLSCHAFT DES ÖSTLICHEN KAISERREICHES.}

\section{(Zusammenfassung)}

Der vorliegende Artikel vergleicht die Gestalt von Hypatios (ca. 366-446) des ersten Igumen der Ruphinianai mit dem Idealbild des spätantiken Heiligen. Kenntnisse über Hypatios sind uns durch die Vita Hypatii bekannt, die bereits kurz nach dem Tod des Igumen Mitte des 5. Jahrhunderts von seinem Jünger Kallinikos verfaßt wurde. Der Hypatios des Kallinikos wird auf die typischen Eigenschaften des spätantiken Heiligen wie: Rückzug aus der Gesellschaft, Befreiung von alltäglichen Bedürfnissen, übermenschliche Fähigkeiten und seine Autorität gegenüber der zeitgenössischen Gesellschaft untersucht. Dabei stellt der Autor gewisse Unterschiede gegenüber dem üblichen Heiligenideal fest.

In der Vita des Hypatios wird weniger nachdrücklich die Askese des Heiligen hervorgehoben als in anderen Lebensbeschreibungen von Heiligen. Dagegen wird immer wieder hervorgehoben, daß sich Hypatios aufgrund seiner Autorität aktiv für die Angelegenheiten der Kirche einsetzt, trotzdem bleibt seine gesellschaftliche Bedeutung begrenzt. Übereinstimmend mit dem Idealbild „des Heiligen” hat sein Gebet Wunderkraft und Hypatios ist mit der Gnade der Heilung und Beherrschung von Dämonen ausgestattet. Die Unterschiede zwischen dem durch Hypatios repräsentierten Heiligenbild und dem allgemeinen Heiligenideal liegen wohl darin begründet, daß Hypatios nicht - wie üblich - aus der Einsamkeit heraus agierte sondern zeitlebens in der Nähe der Hauptstadt mit all ihren karitativen Einrichtungen, dem Bischofssitz und Kaiserhof wirkte. 